\title{
Combating corruption in Singapore: a comparative analysis of two scandals
}

\author{
Jon S.T. Quah \\ Anti-Corruption Consultant, Singapore
}

\begin{abstract}
Purpose - The purpose of this paper is to compare two corruption scandals in Singapore to illustrate how its government has dealt with these scandals and to discuss the implications for its anti-corruption strategy.

Design/methodology/approach - This paper analyses the Teh Cheang Wan and Edwin Yeo scandals by relying on published official and press reports.

Findings - Both scandals resulted in adverse consequences for the offenders. Teh committed suicide on 14 December 1986 before he could be prosecuted for his bribery offences. Yeo was found guilty of criminal breach of trust and forgery and sentenced to 10 years' imprisonment. The Commission of Inquiry found that the Corrupt Practices Investigation Bureau (CPIB) was thorough in its investigations which confirmed that only Teh and no other minister or public official were implicated in the bribery offences. The Independent Review Panel appointed by the Prime Minister's Office to review the CPIB's internal controls following Yeo's offences recommended improvements to strengthen the CPIB's financial procedures and audit system. Singapore has succeeded in minimising corruption because its government did not cover-up the scandals but punished the guilty offenders and introduced measures to prevent their recurrence.
\end{abstract}

Originality/value - This paper will be useful for scholars, policymakers and anti-corruption practitioners interested in Singapore's anti-corruption strategy and how its government handles corruption scandals.

Keywords Corruption scandals, Corrupt Practices Investigation Bureau, Teh Cheang Wan, Edwin Yeo,

Singapore

Paper type Research paper

\section{Introduction}

Singapore is the least corrupt Asian country according to Transparency International's Corruption Perceptions Index (CPI) from 1995 to 2019. In 1995, Singapore was ranked third amongst 41 countries. In 2019, Singapore shared joint fourth ranking with Sweden and Switzerland amongst 180 countries with a score of 85 (Transparency International, 1995, 2020). However, this does not mean that there are no corruption scandals in Singapore (see Yeo, 2014). Scandal is defined by West (2006, p. 6) as "an event in which the public revelation of an alleged private breach of a law or a norm results in significant social disapproval or debate and, usually, reputational damage." A corruption scandal refers to the public exposure of corruption offences that result in social disapproval and reputational damage of the offenders.

This article analyses the corruption scandals in Singapore involving Teh Cheang Wan, the Minister for National Development during 1979-1986, and Edwin Yeo, an Assistant Director of the Corrupt Practices Investigation Bureau (CPIB), which resulted in adverse

(C) Jon S.T. Quah. Published in Public Administration and Policy. Published by Emerald Publishing Limited. This article is published under the Creative Commons Attribution (CC BY 4.0) license. Anyone may reproduce, distribute, translate and create derivative works of this article (for both commercial and non-commercial purposes), subject to full attribution to the original publication and authors. The full terms of this license may be seen at http://creativecommons.org/licences/by/4.0/legalcode

The author wishes to thank Professors Robert Gregory and Chilik Yu for their constructive comments on an earlier version of this paper.

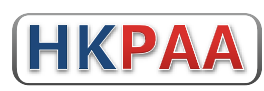

Received 6 November 2019

Revised 8 January 2020 Accepted 27 February 2020 
PAP

23,1

consequences for them. These scandals are selected because both individuals were respectively, the most senior People's Action Party (PAP) minister and CPIB officer charged with committing corruption offences. A comparison of these scandals demonstrates how the CPIB investigates corruption complaints and explains why corruption has been minimised in Singapore. The scandals are analysed first before identifying their consequences and the implications for combating corruption in Singapore.

\section{Teh Cheang Wan scandal}

Teh Cheang Wan was born in China and left in 1935 for Penang, Malaysia, where he received his primary and secondary education. After graduating in architecture at the University of Sydney in 1956, he worked as an architect with the Public Works Department and Housing Commission in New South Wales before working with the Housing Trust in Kuala Lumpur and the Penang City Council in 1957. In August 1959, he joined the Building Department of the Singapore Improvement Trust (SIT) as an architect. When the SIT was replaced by the Housing and Development Board (HDB) in February 1960, Teh was promoted to the position of Chief Architect. He became the HDB's Chief Executive Officer in 1970 and the Chairman of the Jurong Town Corporation in September 1977. He relinquished both positions to participate as a PAP candidate in the Geylang West constituency by-election in January 1979. He was returned unopposed and appointed as the Minister for National Development in February 1979 (Ngoo, 1983, p. 8).

\section{CPIB's investigations}

In April 1984, the CPIB received from an anonymous source a copy of Pek Chee Kee's affidavit of 22 February 1984 alleging that his father, Pek Tiong Seng, had paid $\$ \$ 560,000$ to three nonexisting companies to prevent Hock Tat's property from being acquired by the government in 1981. Pek Chee Kee informed CPIB officers on 5 September 1986 that he complained against the three directors of Hock Tat Company for paying $\mathrm{S} \$ 560,000$ without authorisation and documentation. He indicated that $\$ \$ 500,000$ was taken from this sum and given to some persons but he refused to identify them. When the CPIB officers questioned the directors on 19 November, they confirmed that the money was withdrawn from Hock Tat but did not know what the sum was used for. After further questioning on 20 November, Pek informed the CPIB officers that the $\$ \$ 500,000$ was paid through a person named "Liew" to Teh, the Minister for National Development. "Liew" was later identified as Liaw Teck Kee by Tan Boon Pow (Parliament of Singapore, 1987, pp. 25-26).

Liaw was interrogated by CPIB officers on 20 November for 34 hours and initially denied that he had received money from Hock Tat. On 21 November, Liaw admitted that he had received $\mathrm{S} \$ 500,000$ from Hock Tat for himself but could not prove this. When his request to the CPIB officers to see the prime minister to reveal the identity of person who received the money was rejected, Liaw disclosed that Teh had received the $\$ \$ 500,000$. Liaw also revealed that he had acted as a middleman for Ho Yeow Koon and gave a bribe of $\$ \$ 500,000$ to Teh in 1982 for the alienation of a parcel of State land to Keck Seng Singapore Private Limited. When the three directors of Hock Tat were informed of Liaw's disclosures, they admitted to the CPIB officers that they had given $\mathrm{S} \$ 500,000$ to Teh for his assistance through Liaw (Parliament of Singapore, 1987, pp. 26-27).

On 20 November, Evan Yeo, CPIB's Director, informed Prime Minister Lee Kuan Yew of the allegations against Teh. Lee agreed that the CPIB should continue to investigate discreetly and stressed that Teh had to be prosecuted if he had accepted bribes. Liaw informed the CPIB officers on 25 November that Liu Cho Chit, a friend of Teh, wrote a letter to offer him US\$500,000 to persuade him not to implicate Teh. When he was questioned by the 
CPIB officers, Liu admitted that he had offered US $\$ 500,000$ to Liaw at Teh's request and that the money would be provided by Teh. Liu was then arrested by the CPIB officers. On 27 November, Yeo submitted a detailed report to Prime Minister Lee and requested his approval to initiate an open investigation by questioning Teh and other relevant persons or witnesses. The CPIB's practice was to conduct an open investigation if there were good reasons to avoid damaging the reputation of the person being investigated. Lee approved the CPIB's request for an open investigation on 28 November (Parliament of Singapore, 1987, p. 27).

Teh was questioned at the Istana Villa on 2 December 1986 by CPIB's Director, Evan Yeo and his colleague, Senior Assistant Director Tan Ah Leak. Teh was taken to the CPIB headquarters for further questioning and released on 3 December at 3 a.m., after 16 hours of interrogation. In his written statement to the CPIB, Teh admitted that he had assisted Hock Tat to retain one-third of its land but denied receiving any money from Hock Tat or Keck Seng. He took full responsibility for Liaw's misdeeds because their friendship had given the impression that Liaw was his agent for collecting bribes. He also offered to return the sum of $\mathrm{S} \$ 800,000$. The CPIB officers searched Teh's office and residence but did not find any incriminating evidence. They obtained from the Attorney-General on 3 December a Notice under Section 20 of the Prevention of Corruption Act requiring Teh to provide the CPIB within two weeks a sworn statement indicating all property owned by him and his family in and outside Singapore during the last seven years and any money or property sent out of Singapore by him during the past seven years. Teh was served this Notice on 5 December (Parliament of Singapore, 1987, pp. 27-28).

The CPIB completed its investigations on Teh on 10 December. On 11 December, CPIB's Director Yeo forwarded the investigation papers to the Attorney-General and recommended that Teh be prosecuted because there was sufficient evidence to do so. On 13 December, Teh sent a letter to Prime Minister Lee asserting that he was morally obliged to help Hock Tat recover part of the land acquired for the Ministry of Defence but he did not assist the developer of Riverview Hotel in the sale of the State land. Even though he was innocent of the allegations against him, Teh was willing to accept full responsibility and the prime minister's decision on the matter. Teh also sent a letter to Yeo claiming that he had not asked or received any bribes from Hock Tat or Ho Yeow Koon as alleged by Liaw Teck Kee, that Liaw had taken advantage by persuading Hock Tat and Ho to pay the $\$ \$ 1$ million which he pocketed, and that Liaw's plan was to frame him if Liaw were exposed. On 14 December, Teh committed suicide at his residence by taking an overdose of Amytal barbiturate, without having to comply with the Notice to provide the CPIB with a sworn statement of all his assets (Parliament of Singapore, 1987, pp. 29-30).

\section{Commission of Inquiry}

On 4 March 1987, Chiam See Tong, the opposition Member of Parliament (MP) for Potong Pasir, asked Prime Minister Lee Kuan Yew whether he would initiate a public inquiry into the Teh Cheang Wan scandal. On 26 March, Professor S. Jayakumar, the Second Minister for Law, informed Parliament that the President had appointed a three-member Commission of Inquiry on the previous day with three terms of reference. First, the Commission had to ascertain whether the CPIB was thorough in its investigation of the bribery complaints against Teh and to confirm that no other minister, parliamentary secretary or government officer were involved in these two cases. Its second term of reference was to investigate the circumstances which enabled Teh to accept the two bribes of $\$ \$ 400,000$ each, to ascertain whether other persons were involved with the two bribes, and to review the system used by the Ministry of National Development (MND) for the acquisition or alienation of land, the receipt and acceptance of tenders and the operations of the MND and related companies. The Commission's third term of reference was to refer any persons implicated in the two bribes to 
PAP

23,1

the appropriate authorities and to make recommendations to address any shortcomings of the MND and its companies in preventing corruption (Parliament of Singapore, 1987, pp. 4-5).

Senior State Counsel, Lawrence Ang, was appointed on 6 April 1987 as Counsel to the Commissioners. The inquiry on the first term of reference began on 19 August 1987 with the testimony of Evan Yeo, CPIB's Director, as the first witness. Yeo continued with his testimony on 20 August, and was followed by his colleague, Tan Ah Leak, who provided details of his interview of Teh on 2 December 1986. The third witness, Liaw Teck Kee, described his role in collecting and giving Teh the two bribes given by Hock Tat and Ho Yeow Koon. In his closing speech on 21 August, Ang concluded, based on the evidence provided to the Commission that: (1) the CPIB was thorough in investigating the two allegations of corruption against Teh and (2) the CPIB had pursued all useful leads by interviewing all the public officers and persons involved with the allegations and confirmed that none of them had implicated any other Minister, Parliamentary Secretary or public officer. The Commission also found that Teh accepted bribes by abusing his position as the Minister for National Development to do favours for Hock Tat Development Pte Ltd and Ho Yeow Koon by ignoring established procedures and overriding the views and recommendations of his officers, and that there were no other bribes (Parliament of Singapore, 1987, pp. 6, 24, 34, 41, 55).

The CPIB officers had interviewed 157 persons in their investigation of the bribery allegations against Teh and recorded statements from 134 of them. Before Teh's death on 14 December, 15 senior CPIB officers were involved in investigating Teh's case. However, after his death, all the 43 investigators in the CPIB were assigned to investigate Teh's case. The CPIB officers had also examined and cross-checked the hundreds of entries in the seven bank accounts of Teh's family, the MND files relating to the Hock Tat case, the Ho Yeow Koon case and the successful tenders for the HDB contracts of Hoe Huat Engineering (Parliament of Singapore, 1987, pp. 30, 44).

\section{Edwin Yeo scandal}

Edwin Yeo joined the CPIB in 1998 as a Senior Special Investigator and was appointed in September 2006 as the Head of the Field Research and Technical Support (FRTS) Branch, which provides technical support for the CPIB's investigations and operations. His role was to supervise and provide oversight of the FRTS Branch's functions and to release funds for the payment of monthly operational and ad hoc expenses such as goods and services. As cash cheques were issued by the CPIB's Administration and Support Department to the FRTS Branch to pay for its operational expenses transacted in cash, he applied for an Internet banking account to enable him to access funds meant for the FRTS Branch between 2009 and 2012. The Deputy Public Prosecutor, Navin Thevar, revealed that Yeo had concealed his offences by "rolling over", i.e. by paying off earlier expenses with new funds meant for the FRTS Branch. Yeo had also requested his staff members to persuade some vendors to accept delayed payments of the sums owed to them (Chong, 2014, p. A1; Singapore District Court, 2014).

\section{Yeo's offences}

Yeo began in 2008 by misappropriating $\mathrm{S} \$ 1,200$. When his misconduct was undetected, he was emboldened to misappropriate much larger sums of money from 2009 until he was caught in September 2012. Ironically, he was awarded a Commendation Medal in 2010 by the Prime Minister's Office (PMO) (Yeo, 2014, p. 29). The 21 charges brought against Yeo are described in Table 1, which shows that the amounts misappropriated have increased from $\mathbf{S} \$ 94,703.64$ in 2009 to $\mathbf{S} \$ 1,233,709.40$ in 2012. Apart from the eight charges of misappropriating $\mathbf{S} \$ 1,760,053.35$ and one charge of forgery, Yeo was also charged on 12 counts of spending a total of $\$ \$ 241,030$ on gambling from 4 May to 8 September 2012. 


\begin{tabular}{|c|c|c|c|c|}
\hline No & Year & Description of charges & $\begin{array}{l}\text { Total amount misappropriated } \\
\text { for year }\end{array}$ & $\begin{array}{l}\text { I WO } \\
\text { corruption }\end{array}$ \\
\hline 1 & 2008 & Misappropriated S\$1,200 & $\mathrm{S} \$ 1,200$ & scal \\
\hline 2 & 2009 & Misappropriated $\mathrm{S} \$ 94,703.64$ on many occasions & $\mathrm{S} \$ 94,703.64$ & \\
\hline 3 & 2010 & Misappropriated $\$ \$ 56,002.11$ on many occasions & S $\$ 106,827.11$ & \\
\hline 4 & & Misappropriated $\mathrm{S} \$ 50,825$ on 20 March & & \\
\hline 5 & 2011 & $\begin{array}{l}\text { Misappropriated } \mathbf{S} \$ 323,613.20 \text { between } 24 \\
\text { January and } 16 \text { November }\end{array}$ & $\mathbf{S} \$ 323,613.20$ & 91 \\
\hline 6 & & Forged payment receipt of $\$ \$ 370,755$ in March & & \\
\hline 7 & 2012 & $\begin{array}{l}\text { Misappropriated } \$ \$ 716,768.37 \text { between } 15 \\
\text { February and } 28 \text { August }\end{array}$ & $\mathrm{S} \$ 1,233,709.40$ & \\
\hline 8 & & Misappropriated $\mathrm{S} \$ 470,265.03$ between 4 May and 31 August & & \\
\hline 9 & & $\begin{array}{l}\text { Misappropriated two cars and two motorcycles with a gross } \\
\text { value of } \$ \$ 46,676 \text { in June }\end{array}$ & & \\
\hline 10 & & Spent $\$ \$ 11,950$ on gambling on 4 May & & \\
\hline 11 & & Spent $\$ \$ 10,900$ on gambling on 1 June & & \\
\hline 12 & & Spent $\mathbf{S} \$ 45,550$ on gambling on 3 June & & \\
\hline 13 & & Spent $\mathrm{S} \$ 6,950$ on gambling on 4 June & & \\
\hline 14 & & Spent $\mathbf{S} \$ 16,650$ on gambling on 13 July & & \\
\hline 15 & & Spent $\mathbf{S} \$ 8,250$ on gambling on 30 July & & \\
\hline 16 & & Spent $\mathbf{S} \$ 30,450$ on gambling on 11 August & & \\
\hline 17 & & Spent $\mathrm{S} \$ 23,500$ on gambling on 12 August & & \\
\hline 18 & & Spent $\$ \$ 9,100$ on gambling on 31 August & & \\
\hline 19 & & Spent $\mathrm{S} \$ 32,400$ on gambling on 3 September & & \\
\hline 20 & & Spent $\mathrm{S} \$ 32,750$ on gambling on 7 September & & \\
\hline 21 & & Spent $\$ \$ 12,580$ on gambling on 8 September & & \\
\hline & & Total amount misappropriated from 2008-2012 & $\mathrm{S} \$ 1,760,053.35$ & Description of 21 \\
\hline & & Total amount spent on gambling in 2012 & $\mathrm{~S} \$ 241,030.00(13.7 \%)$ & charges against Edwin \\
\hline \multicolumn{4}{|c|}{ Source(s): Compiled from the information provided in Singh (2013a, p. A6). } & Yeo, 2008-2012 \\
\hline
\end{tabular}

Yeo's offences were discovered on 14 September 2012 when the CPIB received information that several operational expenses incurred by the FRTS Branch were overdue. He was suspended from duty on 15 September after preliminary investigations. The CPIB reported Yeo's offences to the Commercial Affairs Department (CAD) of the Singapore Police Force on 18 October to prevent a conflict of interest and to ensure that the investigation would be conducted independently and impartially.

\section{CPIB's weak internal controls}

Yeo's transgressions for nearly four years reflect poorly on the CPIB's internal controls and procurement procedures on several counts. First, it is indeed surprising that the CPIB's internal audit controls are ineffective in spite of the Auditor-General's repeated recent reminders to ministries and statutory boards in Singapore to strengthen these controls. Jones (2002, p. 31) contends that the Singapore government's procurement policy is shaped by the three principles of following fair practices for all would-be suppliers, ensuring that the public is given value for money in purchasing goods and services, and maintaining the highest standards of probity in the procurement process to minimise the possibility of corruption. Clearly, the third principle of probity was not followed as Yeo deceived his colleague, Sze Chinyu, CPIB's Assistant Director of Administration and Support, that he had paid an equipment supplier by forging a payment receipt of $\$ \$ 370,755$ in March 2011 (Neo, 2014, p. 1). Yeo's ability to forge a payment receipt without being detected indicates the CPIB's lack of effective internal controls governing procurement, including the detection of forged receipts and invoices. 
PAP

23,1

92

Second, it is also surprising that Yeo was allowed to ignore the management's instruction requiring two persons to authorise transactions for a FRTS Branch bank account by applying for Internet banking facilities, which enabled him to transfer $\mathrm{S} \$ 470,265$ from the FRTS Branch account to his personal bank account between May and August 2012 (Neo, 2014, p. 1; Singapore District Court, 2014). As CPIB's Director is responsible for maintaining an effective system of internal controls, Eric Tan, who became CPIB's Director in October 2010, apologised for these lapses in internal control under his watch. When Tan became CPIB's Director, he tightened the CPIB's work processes but these improvements failed to detect Yeo's misconduct until September 2012 because the "new measures were not implemented well and were circumvented" (Toh, 2013, p. A6).

Third, according to paragraph 112 (1) in section L on "Staff and Discipline" in the Instruction Manual 2: Staff, a permanent secretary has to ensure that all the officers in his ministry declare whether they are financially embarrassed when they are first appointed, before they are out on the pensionable establishment, and annually on 1 July or another date decided by the ministry. Like all civil servants in Singapore, CPIB officers are also required to file an annual declaration of indebtedness for unsecured debts of more than three months of their monthly salary and to confirm that they are not financially embarrassed (Quah, 2014, p. 204). Obviously, in Yeo's case, he did not file the annual declaration of indebtedness for four years or his declarations were not properly verified. The CPIB has admitted that there were instances where the procedures and annual declarations were circumvented by Yeo.

Fourth, Yeo's case also illustrates the risks involved in the CPIB's reliance on limited closed tendering, when some reputable suppliers are invited to make submissions for the supply of goods and services without calling for an open or selective tender (Jones, 2002, p. 39 ), because the reduced transparency provides opportunities for backroom deals and procurement officers might be drawn into close relationships with suppliers involved in these deals. Procurement officers in Singapore are required by Instruction Manual 3: Stores, Works and Services to avoid personal contact and face-to-face dealings with the suppliers (Jones, 2014).

Finally, the most troubling aspect of Yeo's case is that as a CPIB officer, he was allowed to visit the two casinos in Singapore and not required to declare these visits to CPIB's Director. As civil servants in Macau are only allowed to visit the casinos there during the first three days of the Chinese Lunar New Year, it is surprising that the Casino Regulatory Authority (CSA) did not recommend restrictions on civil servants visiting the casinos in Singapore after their fact-finding trip to learn from Macau's experience in regulating casinos. Apart from CSA officers and those police officers involved in investigating casino-related cases, who are banned from visiting the two casinos, all police and Central Narcotics Bureau officers are required to declare their visits to these casinos.

Internal controls are necessary to ensure ethical government by reducing opportunities and incentives for corruption and by facilitating its detection. Apart from screening carefully candidates for appointed positions to prevent persons with a record of ethical violations from being appointed, the internal control system must ensure that more than one official is responsible for "authorising, processing, recording, and reviewing transactions." If possible, each of these functions should be performed by a different officer. Top-level supervisors should also review the internal controls periodically to ascertain their effectiveness (Zimmerman, 1994, pp. 216, 223).

\section{Consequences of the two scandals}

Lowi (1988, p. viii) distinguishes between substantive and procedural scandals. The substantive scandal refers to the breach of an actual norm and the procedural scandal involves the subsequent actions to cover-up or minimise the breach. A comparison of the two 
scandals shows that the PAP government did not cover-up both scandals but instead initiated investigations to ascertain why they occurred and introduced measures to prevent their recurrence. In terms of duration, Teh's scandal, which occurred from April 1984 to December 1986, was shorter than Yeo's scandal, which lasted from 2008 to February 2014. There were adverse consequences for both offenders as Thompson (2000, p. 249) observed that "a scandal may culminate in a resignation, prosecution or some other form of careerdiminishing and life-demeaning outcome."

\section{Consequences of Teh's scandal}

During his interview with CPIB officers on 2-3 December 1986, Teh admitted that he had assisted Hock Tat Development to retain its land but denied receiving any money from Hock Tat or Keck Seng. On 13 December, Teh sent letters to Prime Minister Lee Kuan Yew and CPIB's Director Evan Yeo to assert his innocence. The CPIB completed its investigations and forwarded the investigation papers to the Attorney-General on 11 December with a recommendation for Teh's prosecution as there was sufficient evidence to do so. However, before Teh could be charged for his offences, he committed suicide on 14 December without providing the CPIB with a sworn statement of all his assets (Parliament of Singapore, 1987, pp. 28-30). Teh's sudden suicide saddened and shocked many Singaporeans because "corruption allegations against prominent members of the PAP have been rare" (Asiaweek, 1987, pp. 19-20).

The CPIB's investigations revealed that Teh's family owned two houses in Singapore. Its examination of the seven bank accounts of Teh and his family also revealed that a total sum of $\$ \$ 7,296,891.15$ was credited in their accounts from September 1976 to December 1986 (Parliament of Singapore, 1987, pp. 31-32). However, as the Prevention of Corruption Act does not provide for the confiscation of the estate of an offender if he obtains his benefits from corruption, an important consequence of Teh's scandal is the introduction of new legislation to plug this loophole. Accordingly, the Corruption (Confiscation of Benefits) Act 1989 was enacted on 3 March 1989 and Section 4 (1) enables the court to issue a confiscation order against a defendant's estate if he had derived such benefits from corruption.

The Commission of Inquiry found that the CPIB was thorough in its investigations of the bribery complaints and confirmed that no minister or government official was involved except for Teh, who accepted the bribes by abusing his position as the Minister for National Development and ignoring established procedures and overriding the views and recommendations of his officers. The Commission submitted its report to President Wee on 18 December 1987. In his memoirs, the late Prime Minister Lee Kuan Yew (2000, pp. 187189) observed that Teh's downfall was "most dramatic" because:

We had established a climate of opinion which looked upon corruption in public office as a threat to society. Teh preferred to take his life rather than face disgrace and ostracism. I never understood why he took this $\$ \$ 800,000$. He was an able and resourceful architect and could have made millions honestly in private practice.

\section{Consequences of Yeo's scandal}

Yeo committed his first offence in 2008 but all his misdeeds were only discovered on 14 September 2012. He was suspended from duty on the next day after preliminary investigations were conducted. The CPIB referred Yeo's offences to the CAD for an independent and impartial investigation on 18 October 2012 to prevent a conflict of interest in investigating one of its senior officers. After the CAD completed its investigations, Yeo was charged on 24 July 2013 for misappropriating S\$1.76 million. On 20 February 2014, he admitted to four of the 21 charges and was sentenced to 10 years of imprisonment. 
PAP

23,1

94

As most civil servants in Singapore, including CPIB officers, were not required to declare their visits to the two casinos before the exposure of Yeo's offences, this serious omission enabled Yeo to satisfy his gambling addiction by making 372 trips to the casinos over two and a half years. He lost $\$ \$ 478,583.45$ at the casinos between April 2010 and September 2012, and $\$ \$ 263,699.20$ through betting with Singapore Pools during 20082012 (Singapore District Court, 2014). If Yeo were required to declare his visits to the casinos, his frequent visits would have alerted the CPIB to his gambling addiction and resulted in closer supervision of his duties. This glaring omission was rectified when the Public Service Division (PSD) announced that all civil servants were required from 1 October 2013 to declare their visits to the casinos in Singapore. Civil servants who visit the local casinos more than four times a month and those who have an annual pass, which allows unlimited visits for a year, are required to declare their visits to their superior officers within seven days. However, those officers in positions which are vulnerable to bribery must declare every visit to a local casino. The PSD introduced these new rules after reviewing Yeo's offences to strengthen measures to reduce the risk of fraud and corruption. Furthermore, from January 2014, all officers occupying positions which are vulnerable to bribery and exploitation would be rotated every five years. Those officers involved in "transactional work" are required to take at least five consecutive days of leave per year to enable those officers covering their duties to review their work procedures (Chang, 2013, p. A1).

On 24 July 2013, the PMO announced that Prime Minister Lee Hsien Loong appointed an Independent Review Panel (IRP) to investigate the causes of Yeo's offences and to prevent their recurrence by strengthening the CPIB's financial procedures and audit system. The IRP found that supervisory lapses in the CPIB resulted in "deficiencies in internal controls and the loss of public funds" from Yeo's ability to misappropriate $\$ \$ 1.76$ million for almost four years. The IRP's recommendations were implemented by the CPIB without revealing what these changes were (PMO, 2013a, p. 1). As these supervisory lapses occurred during the terms of CPIB's Directors Soh Kee Hean (July 2005 to September 2010) and Eric Tan (October 2010 to September 2013), they were given formal letters of warning by the PMO for their failure to supervise adequately Yeo and the FRTS Branch. As Tan's term as CPIB's Director ended in September 2013, he was succeeded by Wong Hong Kuan, who was appointed on 1 October 2013 by Prime Minister Lee to "maintain public trust and confidence in CPIB" and to implement the IRP's recommendations (PMO, 2013b, p. 1). Tan's replacement by Wong shows "how seriously the Government views the lapses at the CPIB" and its intolerance of such lapses (Tham, 2013, p. A1).

In August 2013, Tharman Shanmugaratnam, Deputy Prime Minister and Finance Minister, informed Parliament that the procurement lapses reported by the Auditor-General's Office (AGO) were due to "non-compliance with rules, rather than gaps in the rules." These lapses resulted from "a lack of knowledge, carelessness or poor supervision, with no evidence of fraud or corrupt intent." He also announced that the new reporting system required permanent secretaries and heads of government agencies to report to the Ministry of Finance annually their assessment of the findings of procurement audits conducted by the AGO or the agencies themselves (Goh, 2013, p. A6). In January 2014, the Ministry of Finance formulated a government procurement code of ethics and professional conduct standards which identified the values and expected behaviour of procurement officers (Ong, 2014, p. B8). The implementation of the IRP's recommendations to strengthen the CPIB's financial procedures and audit system by its new director Wong should enhance its internal controls and procurement procedures.

As trust is a "relatively fragile resource" which can be depleted by a corruption scandal (Thompson, 2000, p. 252), the revelation of Yeo's misappropriation of $\$ \$ 1.76$ million has shocked many Singaporeans and tarnished the CPIB's public image (Quah, 2015, p. 96). To be 
effective, the CPIB must be incorruptible for two reasons. First, if its personnel are corrupt, such corruption would erode the CPIB's legitimacy and public image as they have broken the law instead of enforcing it. Second, corruption amongst CPIB officers prevents them from performing their anti-corruption functions impartially and effectively. Consequently, any CPIB officer found guilty of corruption must be punished and dismissed. Furthermore, details of such punishment must be widely publicised in the mass media to deter other officers to demonstrate the CPIB's integrity and credibility to the public.

Yeo is the third CPIB officer who has been found guilty of corruption offences. Gopal Ramachandran, a CPIB officer with 10 years' experience, was jailed for two years in July 2002 for leaking information to two corrupt policemen on how they would be investigated (Straits Times, 2002, p. 8). A CPIB senior special investigator, Chan Toh Kai, was jailed for one year in 1997 for cheating a businessman of $\$ \$ 8,000$ (CPIB, 2003, p. 5.39). However, Yeo's misappropriation of $\mathrm{S} \$ 1.76$ million was not detected for nearly four years. The detection of Yeo's offences on 14 September 2012 was untimely for the CPIB as it occurred four days before the CPIB's 60th anniversary celebrations on 18 September.

Fortunately, Yeo's scandal did not result in irreparable damage to the public trust in the $\mathrm{CPIB}$ as a comparison of the findings of the public perceptions surveys commissioned by the CPIB in 2013 and 2016 in Table 2 shows that there is a two percentage decrease of respondents providing a positive evaluation of Singapore's anti-corruption efforts and those respondents who could trust the CPIB to keep Singapore corruption free. On the other hand, the proportion of respondents who believed that the CPIB is effective in maintaining Singapore's low level of corruption has increased by one per cent, those respondents indicating that the CPIB has done well in solving corruption cases has risen by three per cent, and those respondents believing that the CPIB is impartial in its investigations has increased by four per cent. Singapore remains the least corrupt Asian country on the CPI from 2013 to 2019, indicating that the revelation of Yeo's scandal in September 2012 has not adversely affected public perceptions of the CPIB's effectiveness.

\section{Implications for Singapore's anti-corruption strategy}

On 26 January 1987, Prime Minister Lee Kuan Yew spoke in Parliament on Teh's suicide on 14 December 1986. He reminded the MPs that "there is no way a Minister can avoid investigations and a trial if there is evidence to support one." Teh "chose death rather than face a trial on the charges of corruption which the Attorney-General had yet to settle." Lee attributed Singapore's effective system of combating corruption to four factors:

\begin{tabular}{lcccc}
\hline & \multicolumn{2}{c}{$\begin{array}{c}\text { Percentage of respondents } \\
\text { agreeing with statement } \\
\text { Change }\end{array}$} \\
Survey item & 2013 & 2016 & Che & \\
\hline Positive evaluation of Singapore's anti-corruption efforts & $91 \%$ & $89 \%$ & $-2 \%$ & \\
The CPIB is effective in maintaining Singapore's low level of corruption & $77 \%$ & $78 \%$ & $+1 \%$ & \\
The CPIB has done well in solving corruption cases & $73 \%$ & $76 \%$ & $+3 \%$ & Table 2. \\
The CPIB is impartial in its investigations & $67 \%$ & $71 \%$ & $+4 \%$ & Public perceptions of \\
the CPIB's \\
The CPIB can be trusted to keep Singapore corruption free & $73 \%$ & $71 \%$ & $-2 \%$ & - \\
Total number of respondents & 1,016 & 1,001 & - & effectiveness in \\
Sources: Compiled from CPIB (2017a, pp. 9-10) and the 2013 CPIB's public perceptions survey findings provided & curbing corruption, \\
by the CPIB & & & & 2013 and 2016 \\
\hline
\end{tabular}


PAP

23,1

96

First, on the law against corruption contained in the Prevention of Corruption Act; second, on a vigilant public ready to give information on all suspected corruption; and third, on a CPIB which is scrupulous, thorough, and fearless in its investigations. For this to be so, the CPIB has to receive the full backing of the Prime Minister under whose portfolio it comes. But the strongest deterrent is in a public opinion which censures and condemns corrupt persons, in other words, in attitudes which make corruption so unacceptable that the stigma of corruption cannot be washed away by serving a prison sentence (Parliament of Singapore, 1987, p. 2).

Even though the number of corruption-related complaints received by the CPIB has declined during 2006-2011, several high-profile corruption scandals were uncovered in Singapore in 2011 and 2012. Ng Boon Gay, the Director of the Central Narcotics Bureau (CNB) was arrested by the CPIB for "serious personal misconduct" on 19 December 2011. He was charged on 12 June 2012 with four counts of corruptly obtaining sexual favours from a former information technology (IT) sales manager, Cecilia Sue, between July and December 2011 (Lim and Tham, 2012a, p. A1). Ng claimed trial for the four charges and the trial began on 25 September 2012. He was acquitted on 14 February 2013 because there was no evidence to show that he was aware that Sue's employer, Hitachi Data Systems, was involved in a contract that he had approved as CNB's Director (Tham and Lim, 2013, p. A1).

On 4 January 2012, Peter Lim, the Commissioner of the Singapore Civil Defence Force (SCDF), was arrested by the CPIB and charged on 6 June on 10 counts of corruption involving sex with three female IT executives, who were seeking government contracts for their companies (Lim and Tham, 2012b, p. A1). Lim's trial began on 18 February 2013 and he was found guilty of corruptly obtaining sexual gratification from the former General Manager of Nimrod Engineering in exchange for business favours with the SCDF on 31 May and sentenced to six months' imprisonment on 13 June (Spykerman, 2013; Today online, 2013). On 21 June 2012, the Ministry of Foreign Affairs revealed that its chief of protocol, Lim Cheng Hoe, was suspended by the Public Service Commission because he was being investigated by the $\mathrm{CAD}$ for making improper expense claims for some of his trips abroad (Lim, 2012, p. A1).

As Yeo's offences were discovered by the CPIB on 14 September 2012 after the revelation of the scandals involving $\mathrm{Ng}$ Boon Gay, Peter Lim and Lim Cheng Hoe, the PMO requested the CAD and CPIB in 2013 to conduct a study of those civil servants investigated for corruption and other financial crimes during 2008-2012 to ascertain whether there was any change in their number or profile (PMO, 2013a, p. 2). Table 3 shows that, an average of $80 \%$ of the cases investigated by the CPIB came from the private sector, with the remaining $20 \%$ originating from the public sector. The number of public sector corruption cases investigated by the CPIB ranges from 31 in 2011 to 49 in 2009, with an average of 39 cases during 20082012. However, the number of private sector corruption cases has declined from 194 in 2008 to 144 in 2012.

In his opening speech at the CPIB's 60th anniversary celebrations on 18 September 2012, Prime Minister Lee Hsien Loong reaffirmed his government's commitment to a policy of zero

Table 3.

Corruption cases investigated by the CPIB by sector, 2008-2012

\begin{tabular}{lccr}
\hline Year & Public sector cases & Private sector cases & Total \\
\hline 2008 & $45(18.8 \%)$ & $194(81.2 \%)$ & $239(100 \%)$ \\
2009 & $49(20.9 \%)$ & $185(79.1 \%)$ & $234(100 \%)$ \\
2010 & $37(18.0 \%)$ & $169(82.0 \%)$ & $206(100 \%)$ \\
2011 & $31(22.5 \%)$ & $107(77.5 \%)$ & $138(100 \%)$ \\
2012 & $35(19.6 \%)$ & $144(80.4 \%)$ & $179(100 \%)$ \\
Average & $39(20.0 \%)$ & $160(80.0 \%)$ & $199(100 \%)$
\end{tabular}

Source(s): Singh (2013b, p. A8) 
tolerance for corruption. According to him, "incorruptibility has become ingrained in the Singaporean psyche and culture" because of the CPIB's impartiality in enforcing the anticorruption laws, its thorough and efficient investigation of corruption cases and the punishment of those found guilty of corruption offences. He indicated that the CPIB's investigation and arrest of $\mathrm{Ng}$ Boon Gay and Peter Lim reflected his government's "determination to clamp down on corruption and wrongdoing even when it's awkward or embarrassing for the Government” (Lee, 2012, p. A23).

Prime Minister Lee justified his government's unequivocal stand against corruption in this way:

Let me be quite clear: We will never tolerate corruption and we will not accept any slackening. Anyone who breaks the rules will be caught and punished - no cover-ups, no matter how senior the officer or how embarrassing it may be. It is far better to suffer the embarrassment and keep the system clean, than to pretend that nothing went wrong and let the rot spread. ... And part of the solution has to be that if you do it, we will catch and punish you. ... Political leaders must continue to set high standards of honesty and integrity. The society must continue to reject corruption - not just because of rules and penalties, but because this reflects the society we want to live in, and the values we hold ourselves to (Lee, 2012, p. A23).

\section{Conclusion}

The effectiveness of Singapore's policy of zero tolerance for corruption and the CPIB's impartial enforcement and punishment of all offenders, regardless of their status, position or political affiliation, is reflected in Singapore's status as the least corrupt Asian country on the CPI from 1995 to 2019 and the continuing trend of declining number of corruption cases investigated by the CPIB during 2013-2018. It can be seen from Table 4 that the number of corruption cases investigated by the CPIB has declined from 152 in 2013 to 107 in 2018 . On average, there were 125 cases during 2013-2018, with 16 (13\%) public sector cases and 109 $(87 \%)$ private sector cases. The average number of corruption cases investigated by the CPIB has declined as Table 3 shows that, there was an average of 199 cases during 2008-2012, with $39(20 \%)$ public sector cases and $160(80 \%)$ private sector cases.

The continuing decline in the number of corruption cases investigated by the CPIB from 2008-2018 indicates that it has been effective in minimising corruption in Singapore. However, this does not mean that there are no corruption scandals in Singapore as shown by the Teh and Yeo scandals, and other scandals. The growing importance of private sector corruption cases from 2008 to 2018 increases the likelihood of future private sector corruption scandals. To address this trend, the CPIB has published a simple four-step guide for business owners to develop and implement an anti-corruption system in their companies in January 2017 (CPIB, 2017b). The CPIB has also developed ISO 37001 on Anti-Bribery Management Systems to assist private companies in Singapore implement an anti-bribery compliance

\begin{tabular}{lccc}
\hline Year & Public sector cases & Private sector cases & Total \\
\hline 2013 & $24(16 \%)$ & $128(84 \%)$ & $152(100 \%)$ \\
2014 & $20(15 \%)$ & $116(85 \%)$ & $136(100 \%)$ \\
2015 & $15(11 \%)$ & $117(89 \%)$ & $132(100 \%)$ \\
2016 & $17(14 \%)$ & $101(86 \%)$ & $118(100 \%)$ \\
2017 & $8(8 \%)$ & $95(92 \%)$ & $103(100 \%)$ \\
2018 & $13(12 \%)$ & $94(88 \%)$ & $107(100 \%)$ \\
Average & $16(13 \%)$ & $109(87 \%)$ & $125(100 \%)$
\end{tabular}

Table 4. Corruption cases investigated by the CPIB by sector, 2013-2018

Source(s): CPIB (2016, p. 6; 2019, p. 5)

corruption scandals in Singapore 
programme in April 2017 (CPIB, 2017a, p. 16). As the CPIB is responsible for investigating effective approach of investigating thoroughly and impartially all future corruption scandals and punishing the guilty offenders according to the law, regardless of their status, position or political affiliation.

\section{References}

Asiaweek (1987), “A matter of honour”, 1 February, pp. 19-20.

Chang, R. (2013), "Civil Servants who frequent casinos must declare visits", Straits Times, 1 October, p. A1.

Chong, E. (2014), "Anti-graft officer gets 10 years jail”, Straits Times, 21 February, p. A1.

Corrupt Practices Investigation Bureau (CPIB) (2003), Swift and Sure Action: Four Decades of AntiCorruption Work, CPIB, Singapore.

CPIB (2016), Annual Report 2015, CPIB, Singapore.

CPIB (2017a), Annual Report 2016, CPIB, Singapore.

CPIB (2017b), PACT: A Practical Anti-Corruption Guide for Businesses in Singapore, CPIB, Singapore.

CPIB (2019), Corruption Statistics 2018, CPIB press release, 25 April, Singapore, pp. 1-16.

Goh, C.L. (2013), "Stricter oversight of procurement audits to prevent lapses", Straits Times, 13 August, p. A6.

Jones, D.S. (2002), "Procurement practices in the Singapore Civil Service: balancing control and delegation", Journal of Public Procurement, Vol. 2 No. 1, pp. 29-53.

Jones, D.S. (2014), "Email correspondence with the author", 18 April.

Lee, H.L. (2012), "Incorruptibility ingrained in S’porean psyche”, Straits Times, 19 September, p. A23.

Lee, K.Y. (2000), From Third World to First, the Singapore Story: 1965-2000, Times Media, Singapore.

Lim, L. (2012), "Senior MFA official under probe over expense claims", Straits Times, 22 June, p. A1.

Lim, L. and Tham, Y.C. (2012a), "Former CNB chief faces graft charges", Straits Times, 13 June, p. A1.

Lim, L. and Tham, Y.C. (2012b), "Former SCDF chief faces 10 charges", Straits Times, 7 June, p. A1.

Lowi, T.J. (1988), "Foreword," in Markovits, A.S. and Silverstein, M. (Eds), The Politics of Scandal: Power and Process in Liberal Democracies, Holmes and Meier Publishers, New York, NY, pp. vii-xi.

Neo, C.C. (2014), "Former CPIB assistant director jailed for 10 years", Today, 21 February, p. 1.

Ngoo, I. (1983), “The late starter who made good: Mr Teh Cheang Wan”, Straits Times, 17 August, p. 8.

Ong, A. (2014), "Public Service 'committed to improving pay, skills”, Straits Times, 6 March, p. B8.

Parliament of Singapore (1987), Report of the Commission of Inquiry on Investigations Concerning the Late Mr Teh Cheang Wan, Cmd. 18 of 1987, Singapore National Printers, Singapore.

Prime Minister's Office (PMO) (2013a), "PMO media statement on case of misappropriation by CPIB officer", Singapore, 24 July, pp. 1-2.

PMO (2013b), “Appointment of Director CPIB”, Singapore, 6 August, pp. 1-2.

Quah, J.S.T. (2014), "Curbing police corruption in Singapore: lessons for other Asian countries”, Asian Education and Development Studies, Vol. 3 No. 3, pp. 186-222.

Quah, J.S.T. (2015), "Singapore's Corrupt Practices Investigation Bureau: four suggestions for enhancing its effectiveness", Asian Education and Development Studies, Vol. 4 No. 1, pp. 76-100.

Singapore District Court (2014), "Public prosecutor v. Yeo Seow Hiong Edwin [2014] SGDC70", 20 February, Suit No. DAC28332-52/13. 
Singh, B. (2013a), "Yeo allegedly started by taking $\$ 1,200$ from CPIB", Straits Times, 27 July, p. A6.

Singh, B. (2013b), "Public service graft cases: half were in enforcement", Straits Times, 27 July, p. A8.

Spykerman, K. (2013), "Ex-SCDF chief Peter Lim found guilty of corruption”, Channel NewsAsia, 31 May.

Straits Times (2002), “CPIB officer gets jail for leaking information”, 4 July, p. 8.

Tham, Y.C. (2013), "CPIB to get new chief”, Straits Times, 7 August, p. A1.

Tham, Y.C. and Lim, J. (2013), “Court Finds Ng Boon Gay not guilty of corruption”, Straits Times, 15 February, p. A1.

Thompson, J.B. (2000), Political Scandal: Power and Visibility in the Media Age, Polity Press, Cambridge, UK.

Today online (2013), "Ex-SCDF chief Peter Lim to Start prison sentence today", 26 June.

Toh, E. (2013), “CPIB director 'didn't implement changes well”, Straits Times, 13 August, p. A9.

Transparency International (1995), "1995 TI Corruption Index”, Berlin, available at: https://www. transparency.org/files/content/tool/1995_CPI_EN.pdf (accessed 29 June 2019).

Transparency International (2020), Corruption Perceptions Index 2019, Berlin.

West, M.D. (2006), Secrets, Sex, and Spectacle: The Rules of Scandal in Japan and the United States, University of Chicago Press, Chicago.

Yeo, S.F. (2014), Men Misbehaving: Men Who Commit Murder, Fraud and Other Crimes in Singapore, Marshall Cavendish International (Asia), Singapore.

Zimmerman, J. (1994), Curbing Unethical Behavior in Government, Greenwood Press, Westport, CT.

\begin{abstract}
About the author
Jon S.T. Quah is a retired Professor of Political Science at the National University of Singapore and an anti-corruption consultant based in Singapore. He has conducted research on corruption in Asian countries since 1977 and his recent books include: Combating Asian Corruption: Enhancing the Effectiveness of Anti-Corruption Agencies (2017); Hunting the Corrupt "Tigers" and "Flies" in China (2015); Minimizing Corruption in China (2013); Curbing Corruption in Asian Countries: An Impossible Dream? $(2011,2013)$ and Taiwan's Anti-Corruption Strategy (2010). Jon S.T. Quah can be contacted at: jonstquah@gmail.com
\end{abstract}

For instructions on how to order reprints of this article, please visit our website:

www.emeraldgrouppublishing.com/licensing/reprints.htm

Or contact us for further details: permissions@emeraldinsight.com 